\title{
Pengaruh Tambahan Penghasilan Terhadap Disiplin Kerja Pada Organisasi
}

\author{
Mhd. Dani Habra ${ }^{1}$ Alistraja Dison Silalahi ${ }^{2}$ Dedy juliandri Panjaitan ${ }^{3}$ \\ Fakultas Ekonomi, Universitas Muslim Nusantara Al Washliyah ${ }^{1,2,3}$ \\ E-mail: danihabraumn@gmail.com
}

\begin{abstract}
Abstrak
Tujuan artikel ini adalah untuk mengetahui pengaruh tambahan penghasilan terhadap disiplin kerja pada dan mengetahui seberapa besar tambahan penghasilan mempengaruhi disiplin kerja pada organisasi Universitas Muslim Nusantara Al Washliyah dengan populasi dan sampel pegawai. Teknik pengumpulan data yang digunakan adalah dengan menggunakan kuesioner yang diberikan kepada setiap responden. Data diproses dengan menggunakan SPSS versi 20.0 for windows. Teknik analisis data yang digunakan adalah regresi linier sederhana, dengan rumus $Y=a+b X$ $+e$, dan untuk mengetahui seberapa besar pengaruh tambahan penghasilan terhadap disiplin kerja pada Organisasi Universitas Muslim Nusantara Al Washliyah menggunakan uji t (parsial). Berdasarkan uji t diketahui bahwa hasil yang diperoleh dari tambahan penghasilan $(X)$ memiliki nilai $t_{\text {hitung }} 8.098>t_{\text {tabel }} 2,035$, artinya berpengaruh positif dan signifikan terhadap disiplin kerja $(Y)$. Maka Ha diterima karena $t_{\text {hitung }}>t_{\text {tabel }}$, sehingga tambahan penghasilan secara parsial cukup berpengaruh terhadap disiplin kerja pada Organisasi Universitas Muslim Nusantara Al Washliyah. Berdasarkan uji regresi linier sederhana, maka diperoleh persamaan nilai konstanta sebesar (a) 14,945 dan $b$ sebesar 1,001, sehingga diperoleh persamaan regresi linier sederhana $Y=14,945$ $+0,644 X+e$, dimana tambahan penghasilan mempunyai pengaruh yang signifikan terhadap variabel disiplin kerja. Nilai koefisien determinan $\left(R^{2}\right)$ diperoleh sebesar 0,679 atau 67,9\% yang berarti bahwa variabel tambahan penghasilan cukup berpengaruh terhadap disiplin kerja pada Organisasi Universitas Muslim Nusantara Al Washliyah.
\end{abstract}

Kata Kunci : Tambahan Penghasilan, Disiplin Kerja, Manajemen Kompensasi

The purpose of this article is to know the effect of additional income on the discipline on work and to find out how much extra income affects the work discipline of the Muslim University of Nusantara Al Washliyah organization with the population and sample of employees. Data collection technique used is to use questionnaires given to each respondent. Data is processed using SPSS version 20.0 for windows. The data analysis technique used is simple linear regression, with the formula $Y=a+b X+e$, and to find out how much influence additional income to work discipline at Organization Muslim University Nusantara Al Washliyah using t test (partial). Based on the t test, it is known that the result obtained from the additional income $(X)$ has a value of $t$ count 8.098> ttable 2.035, it means a positive and significant effect on the work discipline (Y). Then $\mathrm{Ha}$ is accepted because thitung > ttabel, so additional income partially enough influence on work discipline at Organization Muslim University Nusantara Al Washliyah. Based on simple linear regression test, we get the equation of constant value equal to (a) 14,945 and $b$ equal to 1,001, so obtained by simple linear regression equation $Y=14,945+$ $0,644 X+e$, where additional income have significant influence to work discipline variable. The value of determinant coefficient (R2) is 0.679 or $67.9 \%$, which means that the additional variable of income is enough to affect the work discipline at the Muslim University Organization Nusantara Al Washliyah.

Keywords : Supplementary Income, Work Discipline, Compensation Management 


\section{PENDAHULUAN}

Peningkatan kinerja dapat dilakukan dengan cara menciptakan disiplin kerja, karena disiplin kerja yang dikelola dengan baik akan menghasilkan kepatuhan pegawai terhadap berbagai peraturan organisasi yang bertujuan meningkatkan kinerja. Kedisiplinan adalah kesadaran dan kesediaan seseorang menaati semua peraturan dan norma-norma sosial yang berlaku. Adanya tingkat disiplin kerja yang baik mencerminkan kredibilitas pegawai mencapai suatu hasil kerja yang optimal untuk mencapai tujuan organisasi.

Pemberian tambahan penghasilan yang adil sangat dibutuhkan oleh setiap Pegawai karena dengan adanya pemberian tambahan penghasilan secara adil, maka pegawai akan merasa dihargai atas usaha yang dicurahkan untuk organisasi. Tambahan penghasilan yang diberikan yaitu berupa tunjangan khusus diluar gaji pokok.

Salah satu upaya organisasi dalam mempertahankan kerja pegawai adalah dengan cara memperhatikan disiplin pegawai yang merupakan salah satu faktor penting untuk mendapatkan hasil kerja yang optimal. Kinerja berkaitan dengan tingkat absensi, semangat kerja, keluhan-keluhan, ataupun masalah vital organisasi. Disiplin Kerja merupakan hal penting yang harus dicapai oleh setiap organisasi termasuk pada Organisasi Universitas Muslim Nusantara Al Washliyah, karena disiplin kerja merupakan cerminan bagi kemampuan organisasi dalam mengelola dan mengalokasikan pegawai. Oleh karena itu, disiplin kerja para pegawai mempunyai pengaruh yang sangat penting bagi berlangsungnya kegiatan organisasi dan berpengaruh bagi proses pencapaian tujuan organisasi.

Disiplin merupakan fungsi manajemen sumber daya manusia yang terpenting, karena semakin baik disiplin pegawai, semakin tinggi produktivitas yang dapat dicapainya. Tanpa disiplin pegawai yang baik, sulit bagi organisasi mencapai hasil yang optimal. Salah satu unsur pencapaian tujuan organisasi adalah tingginya produktivitas, efektivitas, efisiensi, serta kepuasan kerja dari pegawai.

Kompensasi merupakan salah satu fungsi yang penting dalam Manajemen Sumber Daya Manusia (MSDM). Karena kompensasi merupakan salahsatu aspek yang paling sensitif didalam hubungan kerja. Kasus yang terjadi dalam hubungan kerja mengandung masalah kompensasi dan berbagai segi yang terkait, seperti tunjangan, kenaikan kompensasi, struktur kompensasi dan skala kompensasi. Kompensasi meliputi bentuk pembayaran tunai langsung, pembayaran tidak langsung dalam bentuk manfaat karyawan dan insentif untuk memotivasi karyawan agar bekerja keras untuk mencapai produktivitas yang semakin tinggi.

\section{METODE PENELITIAN}

Tempat penelitian di Universitas Muslim Nusantara Al-Washliyah, Jalan Garu II No. 93 Medan, Sumatera Utara. Waktu kegiatan penelitian dimulai bulan Agustus 2017- Desember 2017.

\section{Metode dan Desain Penelitian}

1. Metode Penelitian

Metode penelitian ini adalah development research.

\section{Indikator Penelitian}

$\begin{array}{clc}\text { Dari } & \text { sub variabel yang } & \text { sudah } \\ \text { didapat, } & \text { maka peneliti } & \text { dapat }\end{array}$ menjabarkan indikator-indikator sebagai berikut:

1. Indikator variabel Tambahan Penghasilan adalah :

a. Absen Pagi/ datang

b. Absen Sore/ Pulang

c. Laporan Kineja dan

d. Kehadiran di kantor pada hari dan jam kerja.

2. Indikator variabel Disiplin Kerja menurut Singodimejo (2010:90) adalah : 

a. Taat terhadap aturan waktu;
b. Taat terhadap peraturan organisasi;
c. Taat terhadap aturan perilaku dalam pekerjaan dan
d. Taat terhadap peraturan lainnya didalam organisasi.

\section{Pengukuran Skala Variabel}

Dalam operasionalisasi variabel ini semua variabel diukur oleh instrumen pengukur dalam bentuk kuesioner yang memenuhi pernyataan-pernyataan tipe skala likert. Skala likert menurut Sugiyono (2010:107) adalah "Skala Likert digunakan untuk mengukur sikap, pendapat dan persepsi seseorang atau sekelompok orang tentang fenomena sosial".

Variabel dan skala pengukuran yang akan diteliti beserta indikatornya disajikan dalam tabel berikut :

Tabel . Pengukuran Skala Variabel

\begin{tabular}{|c|c|c|c|}
\hline Variabel & Definisi Variabel & Indikator & Skala \\
\hline $\begin{array}{l}\text { Tambahan } \\
\text { Penghasilan } \\
\text { (X) }\end{array}$ & $\begin{array}{l}\text { Tambahan penghasilan } \\
\text { tambahan penghasilan } \\
\text { Pegawai dan dosen yang } \\
\text { diberikan diluar gaji pokok } \\
\text { berdasarkan kriteria kedisiplinan } \\
\text { dan beban kerja }\end{array}$ & $\begin{array}{ll}\text { 1. } & \text { Absen Pagi/ Datang } \\
\text { 2. } & \text { Absen sore/ pulang } \\
\text { 3. } & \text { Laporan Kinerja } \\
\text { 4. } & \text { Kehadiran di Kantor pada } \\
\text { hari dan jam kerja }\end{array}$ & Likert \\
\hline $\begin{array}{l}\text { Disiplin } \\
\text { (Y) }\end{array}$ & $\begin{array}{l}\text { Disiplin kerja adalah kesadaran } \\
\text { dan kerelaan seseorang dalam } \\
\text { menaati semua peraturan } \\
\text { perusahaan dan norma-norma } \\
\text { sosial yang berlaku }\end{array}$ & $\begin{array}{l}\text { 1. Taat terhadap aturan } \\
\text { waktu } \\
\text { 2. Taat terhadap peraturan } \\
\text { organisasi } \\
\text { 3. Taat terhadap aturan } \\
\text { perilaku dalam pekerjaan } \\
\text { 4. Taat terhadap peraturan } \\
\text { lainnya didalam organisasi }\end{array}$ & Likert \\
\hline
\end{tabular}

Sumber: Data diolah Peneliti, 2017

\section{Teknik Pengumpulan Data}

Teknik pengumpulan data penelitian dilakukan adalah dengan cara sebagai berikut :

1. Observasi

Observasi adalah pengumpulan data yang dilakukan dengan mengamati secara langsung kondisi objek penelitian.

2. Studi Dokumentasi/ Studi Pustaka Studi dokumentasi yaitu melakukan pengumpulan data dengan cara membaca dan mempelajari dokumen, buku-buku, literatur yang berhubungan dengan masalah yang diteliti.

3. Daftar Pertanyaan (Kuesioner)

Kuesioner yaitu teknik pengumpulan data dengan cara menyiapkan satu set pertanyaan yang tersusun secara sistematis dan standar yang diberikan kepada responden untuk dijawab tentang variabel-variabel tambahan penghasilan terhadap disiplin kerja, kemudian dari jawaban itu diberikan skornya dengan skala likert. Skala Likert mempunyai interval 1-5. Untuk jawaban yang mendukung pertanyaan atau pernyataan diberi skor tertinggi dan untuk jawaban yang tidak mendukung pertanyaan atau pernyataan diberi skor terendah. Tabel. Skala Likert

\begin{tabular}{|l|c|}
\hline \multicolumn{1}{|c|}{ Keterangan Jawaban } & $\begin{array}{c}\text { Bobot } \\
\text { Nilai }\end{array}$ \\
\hline Sangat Setuju (SS) & 5 \\
\hline Setuju (S) & 4 \\
\hline Ragu-ragu (R) & 3 \\
\hline Tidak Setuju (ST) & 2 \\
\hline Sangat Tidak Setuju (STS) & 1 \\
\hline
\end{tabular}

Sumber: Sugiyono (2010:107) 


\section{Teknik Analisis Data}

\section{Uji Validitas}

Uji Validitas untuk mengukur apakah data didapat setelah penelitian merupakan data yang valid dengan alat ukur yang digunakan (kuesioner). Dalam penelitian ini sampel uji validitas diambil sebanyak 33 orang pegawai diambil dari pada sampel dengan menggunakan program SPSS 20.0 for windows dengan kriteria (Sugiyono, 2010:125) sebagai berikut :

a. Jika $r_{\text {hitung }}>r_{\text {tabel }}$, maka pertanyaan tersebut dikatakan valid.

b. Jika $r_{\text {hitung }}<r_{\text {tabel }}$, maka pertanyaan tersebut dikatakan tidak valid.

\section{Uji Reliabilitas}

Dalam penelitian ini dilakukan uji validitas dan reliabilitas dengan menggunakan bantuan program SPSS 20,0 for windows, butiran pertanyaan yang sudah valid dalam uji validitas akan ditentukan reliabilitasnya dengan kriteria (Sugiyono, 2010:129) sebagai berikut :

a. Jika $r_{\text {alpha }}$ positif atau $>r_{\text {tabel, }}$ maka pernyataan reliabel.

b. Jika $r_{\text {alpha }}$ negatif atau $<r_{\text {tabel, }}$ maka pernyataan tidak reliabel.

\section{Analisis Regresi Linier \\ Sederhana}

Rumus regresi linier sederhana sebagai berikut :

$\mathbf{Y}=\mathbf{a}+\mathbf{b X}+\mathbf{e}$

Keterangan:

$\mathrm{Y}=$ Disiplin Kerja

$\mathrm{X}=$ Tambahan Penghasilan

$\mathrm{A}=$ Konstanta

$\mathrm{b}=$ Koefisien

$\mathrm{e}=$ Standart Error

Tabel . Pedoman Memberikan

Interprestasi Koefisien Korelasi

\begin{tabular}{|l|l|}
\hline Interval Koefisien & $\begin{array}{l}\text { Tingkat } \\
\text { Hubungan }\end{array}$ \\
\hline $0,00-0,199$ & Sangat Rendah \\
\hline $0,20-0,399$ & Rendah \\
\hline $0,40-0,599$ & Sedang \\
\hline $0,60-0,799$ & Kuat \\
\hline $0,80-1,000$ & Sangat Kuat \\
\hline
\end{tabular}

Sumber: Sugiyono (2010:147)

\section{Uji T (Parsial)}

Uji T (parsial) yaitu uji secara parsial untuk membuktikan hipotesis awal tentang Pengaruh Tambahan Penghasilan (X) sebagai variabel bebas terhadap Disiplin Kerja (Y) sebagai variabel terikat. Taraf signifikasi $95 \%$ dengan $\alpha=5 \%$.

Menurut Sugioyono (2010:184) kriteria pengambilan keputusan yaitu :

a. Ho diterima jika $\mathrm{t}_{\text {hitung }}<\mathrm{t}_{\text {tabel }}$ pada $\alpha=$ $5 \%$.

b. Ha diterima jika $t_{\text {hitung }}>t_{\text {tabel }}$ pada $\alpha=$ $5 \%$.

$$
t=\frac{r \sqrt{n-2}}{\sqrt{1+r^{2}}}
$$

\section{Koefisien Determinan $\left(\mathbf{R}^{2}\right)$}

Uji koefisien determinan digunakan untuk melihat seberapa besar kontribusi variabel bebas terhadap variabel terikat. Menurut Sugiyono (2010:199) semakin besar nilai koefisien determinan maka semakin baik kemampuan variabel $(\mathrm{X})$ menerangkan variabel $(\mathrm{Y})$.

$$
\begin{aligned}
& \mathrm{D}=\mathbf{r}^{2} \times \mathbf{1 0 0 \%} \\
& \text { Keterangan: }
\end{aligned}
$$

$$
\begin{aligned}
& \mathrm{D} \quad=\quad \text { Koefisien } \\
& \text { determinan } \\
& \mathrm{r}^{2}=\text { Koefisien } \\
& \text { dikuadratkan }
\end{aligned}
$$

\section{HASIL DAN PEMBAHASAN \\ Korelasi Product Moment}

Berdasarkan hasil analisis data pada lampiran, maka dapat disimpulkan dari angket penelitian, yang akan digunakan dalam menghitung korelasi adalah sebagai berikut: $\sum x y=57027$

Untuk mengetahui apakah hubungan variabel $\mathrm{x}$ dengan y signifikan atau tidak, dapat diketahui melalui perhitungan berikut ini dengan menggunakan rumus korelasi product moment yaitu $: \mathrm{r} \quad \mathrm{xy}=0,824034$ (dibulatkan 0,824) 


\begin{tabular}{|l|r|r|l|l|}
\hline Model & $\mathrm{R}$ & $\begin{array}{r}\text { R } \\
\text { Squ } \\
\text { are }\end{array}$ & $\begin{array}{l}\text { Adjust } \\
\text { ed R } \\
\text { Square }\end{array}$ & $\begin{array}{l}\text { Std. } \\
\text { Error of } \\
\text { the } \\
\text { Estimate }\end{array}$ \\
\hline 1 & $\begin{array}{r}, 82 \\
4^{\mathrm{a}}\end{array}$ &, 679 &, 669 & 2,44260 \\
\hline
\end{tabular}

a. Predictors : (Constant), Tambahan Penghasilan

Hasil perhitungan di atas yaitu $r_{x y}$ $=0,824$ adalah korelasi antara variabel tambahan penghasilan (X) dengan variabel disiplin kerja (Y) adalah positif atau dengan kata lain, mempunyai hubungan positif yang sangat kuat.

Untuk mengetahui tinggi rendahnya hubungan tersebut dapat digunakan pedoman untuk memberikan interprestasi koefisien korelasi sebagai berikut :

\section{Pedoman Untuk Memberikan Interprestasi Koefisien Korelasi}

\begin{tabular}{|l|l|}
\hline Interval Koefisien & Tingkat Hubungan \\
\hline $0,00-0,199$ & Sangat Rendah \\
$0,20-0,399$ & Rendah \\
$0,40-0,599$ & Sedang \\
$0,60-0,799$ & Kuat \\
$0,80-1,000$ & Sangat Kuat \\
\hline
\end{tabular}

Sumber: Sugiyono (2010:113)

Berdasarkan hasil perhitungan diperoleh $\mathrm{r}_{\mathrm{xy}}=0,824$ berarti pengaruh tambahan penghasilan terhadap disiplin kerja pada Organisasi Universitas Muslim Nusantara Al Washliyah adalah Sangat Kuat.

\section{Uji Validitas} adalah :

Kriteria pengambilan keputusan

1. Jika $r_{\text {hitung }}>r_{\text {tabel }}$ maka dinyatakan valid.

2. Jika $r_{\text {hitung }}<r_{\text {tabel }}$ maka dinyatakan tidak valid.

Tabel. Uji Validitas Instrumen Variabel Tambahan Penghasilan (X) Item-Total Statistics

\begin{tabular}{|c|c|c|c|c|}
\hline & $\begin{array}{c}\text { Scale Mean if } \\
\text { Item Deleted }\end{array}$ & $\begin{array}{c}\text { Scale Variance } \\
\text { if Item Deleted }\end{array}$ & $\begin{array}{c}\text { Corrected } \\
\text { Item-Total } \\
\text { Correlation }\end{array}$ & $\begin{array}{c}\text { Cronbach's } \\
\text { Alpha if Item } \\
\text { Deleted }\end{array}$ \\
\hline VAR00001 & 36,7576 & 27,314 &, 362 &, 854 \\
VAR00002 & 37,3939 & 21,121 &, 787 &, 815 \\
VAR00003 & 36,6667 & 26,792 &, 466 &, 848 \\
VAR00004 & 37,3939 & 21,121 &, 787 &, 815 \\
VAR00005 & 37,3636 & 24,489 &, 383 &, 860 \\
VAR00006 & 37,1212 & 26,485 &, 364 &, 865 \\
VAR00007 & 37,4848 & 20,883 &, 823 &, 811 \\
VAR00008 & 36,6970 & 27,218 &, 379 &, 853 \\
VAR00009 & 36,6364 & 26,864 &, 455 &, 849 \\
VAR00010 & 37,3939 & 20,434 &, 910 &, 802 \\
\hline
\end{tabular}

Sumber : Hasil Perhitungan SPSS 20,0 (data diolah), 2017

Berdasarkan tabel diatas diperoleh bahwa pengujian dari variabel tambahan penghasilan memiliki nilai yang lebih besar dari 0,344. Dengan demikian dapat disimpulkan bahwa seluruh pernyataan dari tambahan penghasilan yang digunakan adalah valid dan dapat digunakan dalam penelitian.

Pengujian validitas dalam penelitian ini menggunakan SPSS 20,0 for windows. Dalam hal ini peneliti menggunakan kuesioner yang terdiri dari 10 butir pernyataan tentang tambahan penghasilan dan 10 butir tentang disiplin kerja, sehingga jumlah keseluruhan pernyataan 20 butir. Setiap butir disiapkan 5 interval jawaban. Jawaban terendah diberi skor 1 dan tertinggi diberi skor 5 . 
Pada tabel di bawah ini menunjukkan :

1. Scale Mean If Item Deleted menerangkan statistik data per item, yaitu nilai rata-rata total variabel jika dihapuskan.

2. Scale variance if deleted menerangkan besarnya varian total jika variabel (butir) tersebut dihapuskan.

Corrected item-total correlation merupakan korelasi antara skor item dengan skor total item yang dapat digunakan untuk menguji validitas instrumen untuk mengetahui butir pernyataan harus dibandingkan dengan $\mathrm{r}_{\text {tabel }}$ untuk mengetahui validitas pada setiap item pernyataan. Dimana $r_{\text {tabel }} \alpha=$ $5 \%$ dengan derajat kebebasan (df) pada taraf signifikan 0,05 dengan $\mathrm{n}=33$ adalah sebesar 0,344.

Dari hasil pengolahan data dengan bantuan program SPSS 20,0 for windows, maka diperoleh hasil uji validitas dengan melihat perbandingan antara $r_{\text {hitung }}$ dengan $r_{\text {tabel }}$ sebagai berikut:

Tabel . Hasil Uji Validitas Instrumen Variabel Tambahan Penghasilan (X)

\begin{tabular}{|l|l|l|l|}
\hline $\begin{array}{l}\text { Pernyata } \\
\text { an }\end{array}$ & $\begin{array}{l}\text { Correcte } \\
\text { d Item } \\
\text { Total } \\
\text { Correlati }\end{array}$ & $\mathbf{r}_{\text {tabel }}$ & $\begin{array}{l}\text { Validit } \\
\text { as }\end{array}$ \\
\hline
\end{tabular}

\begin{tabular}{|l|l|l|l|}
\hline & $\begin{array}{l}\text { on } \\
\left(\mathbf{r}_{\text {hitung }}\right)\end{array}$ & $\begin{array}{l}0,34 \\
4\end{array}$ & Valid \\
\hline Item 1 & 362 & $\begin{array}{l}0,34 \\
4\end{array}$ & Valid \\
\hline Item 2 &, 787 & $\begin{array}{l}0,34 \\
4\end{array}$ & Valid \\
\hline Item 3 &, 466 & $\begin{array}{l}0,34 \\
4\end{array}$ & Valid \\
\hline Item 4 &, 787 & $\begin{array}{l}0,34 \\
4\end{array}$ & Valid \\
\hline Item 5 &, 383 & $\begin{array}{l}0,34 \\
4\end{array}$ & Valid \\
\hline Item 6 &, 364 & $\begin{array}{l}0,34 \\
4\end{array}$ & Valid \\
\hline Item 7 &, 823 & $\begin{array}{l}0,34 \\
4\end{array}$ & Valid \\
\hline Item 8 &, 379 & $\begin{array}{l}0,34 \\
4\end{array}$ & Valid \\
\hline Item 9 &, 455 & $\begin{array}{l}0,34 \\
4\end{array}$ & Valid \\
\hline Item 10 &, 910 & \\
\hline
\end{tabular}

Sumber : Hasil Perhitungan SPSS 20,0 (data diolah), 2017

Dari tabel diatas diperoleh nilai Corrected Item Total Correlation ( $\mathrm{r}_{\text {hitung }}$ ) tertinggi pada item 10 sebesar 0,910, dimana hasil analisis $r_{\text {hitung }} 0,910>r_{\text {tabel }}$ 0,344 dan nilai terendah pada item 1 sebesar 0,362, dimana akan diperoleh hasil $r_{\text {hitung }} 0,362>r_{\text {tabel }} 0,344$. Sehingga dapat disimpulkan bahwa penelitian instrumen tambahan penghasilan berupa kuesioner ini adalah valid.

Tabel. Uji Validitas Instrumen Variabel Displin Kerja (Y)

Item-Total Statistics

\begin{tabular}{|l|r|r|l|l|}
\hline & $\begin{array}{l}\text { Scale Mean if } \\
\text { Item Deleted }\end{array}$ & $\begin{array}{l}\text { Scale Variance } \\
\text { if Item Deleted }\end{array}$ & $\begin{array}{l}\text { Corrected } \\
\text { Item-Total } \\
\text { Correlation }\end{array}$ & \multicolumn{2}{l|}{$\begin{array}{l}\text { Cronbach's } \\
\text { Alpha if Item } \\
\text { Deleted }\end{array}$} \\
\hline VAR00001 & 37,3636 & 14,801 &, 557 &, 802 \\
VAR00002 & 37,4242 & 16,314 &, 369 &, 829 \\
VAR00003 & 37,0000 & 15,562 &, 546 &, 806 \\
VAR00004 & 37,2424 & 14,127 &, 691 &, 788 \\
VAR00005 & 37,0909 & 15,273 &, 559 &, 804 \\
VAR00006 & 37,8485 & 15,320 &, 390 &, 836 \\
VAR00007 & 37,1818 & 16,716 &, 381 &, 825 \\
VAR00008 & 37,4242 & 14,064 &, 710 &, 786 \\
VAR00009 & 37,4242 & 12,939 &, 737 &, 778 \\
VAR00010 & 37,3636 & 13,614 &, 546 &, 805 \\
\hline
\end{tabular}

Sumber : Hasil Perhitungan SPSS 20,0 (data diolah), 2017 
Berdasarkan tabel diatas diperoleh bahwa pengujian dari variabel disiplin kerja memiliki nilai yang lebih besar dari 0,344. Dengan demikian dapat disimpulkan bahwa seluruh pernyataan dari disiplin kerja yang digunakan adalah valid dan dapat digunakan dalam penelitian.

Tabel . Hasil Uji Validitas Instrumen Variabel Disiplin Kerja

\begin{tabular}{|l|l|l|l|}
\hline \multicolumn{2}{|c|}{$\left(\begin{array}{l}\text { Pernyata } \\
\text { an } \\
\begin{array}{l}\text { d Item } \\
\text { Total } \\
\text { Correlati } \\
\text { on } \\
\text { (rhitung) }\end{array}\end{array}\right.$} & $\mathbf{r}_{\text {tabel }}$ & $\begin{array}{l}\text { Validit } \\
\text { as }\end{array}$ \\
\hline Item 1 &, 557 & $\begin{array}{l}0,34 \\
4\end{array}$ & Valid \\
\hline Item 2 &, 369 & $\begin{array}{l}0,34 \\
4\end{array}$ & Valid \\
\hline Item 3 &, 546 & $\begin{array}{l}0,34 \\
4\end{array}$ & Valid \\
\hline Item 4 &, 691 & $\begin{array}{l}0,34 \\
4\end{array}$ & Valid \\
\hline Item 5 &, 559 & $\begin{array}{l}0,34 \\
4\end{array}$ & Valid \\
\hline Item 6 &, 390 & $\begin{array}{l}0,34 \\
4\end{array}$ & Valid \\
\hline Item 7 &, 381 & $\begin{array}{l}0,34 \\
4\end{array}$ & Valid \\
\hline Item 8 &, 710 & $\begin{array}{l}0,34 \\
4\end{array}$ & Valid \\
\hline Item 9 &, 737 & $\begin{array}{l}0,34 \\
4\end{array}$ & Valid \\
\hline Item 10 &, 546 & $\begin{array}{l}0,34 \\
4\end{array}$ & Valid \\
\hline
\end{tabular}

Sumber : Hasil Perhitungan SPSS 20,0 (data diolah), 2017

Dari tabel ditas diperoleh nilai Corrected Item Total Correlation $\left(\mathrm{r}_{\text {hitung }}\right.$ ) tertinggi pada item 9 sebesar 0,737, dimana hasil analisis $r_{\text {hitung }} 0.737>r_{\text {tabel }}$ 0,344 dan nilai terendah pada item 2 sebesar 0,369, dimana akan diperoleh hasil $r_{\text {hitung }} 0,369>r_{\text {tabel }} 0,344$. Sehingga dapat disimpulkan bahwa penelitian instrumen variabel disiplin kerja berupa kuesioner ini adalah valid.

\subsubsection{Uji Reliabilitas}

Reliabilitas instrumen digunakan untuk melihat apakah alat ukur yang digunakan menunjukkan konsistensi dalam mengukur gejala yang sama. Setelah dilakukan uji validitas, maka selanjutnya adalah mengukur reliabilitas dari butir pernyataan.

Untuk mengetahui tinggi rendahnya hubungan tersebut dapat digunakan pedoman untuk memberikan interprestasi koefisien korelasi sebagai berikut :

Tabel dibawah menunjukkan hasil pengujian reliabilitas pada instrumen tambahan penghasilan dan disiplin kerja dengan nilai cronbach's alpha atau $\mathrm{r}_{\text {alpha }}$, pernyataan tersebut reliabel karena $r_{\text {alpha }}>r_{\text {tabel. }}$ Ini menunjukkan semua butir dari variabel tambahan penghasilan tersebut dapat digunakan untuk memperoleh data penelitian.

Tabel. Cronbach's Alpha Variabel Independent Tambahan Penghasilan (X)

(X) Reliability Statistics

\begin{tabular}{|c|l|}
\hline $\begin{array}{l}\text { Cronbach's } \\
\text { Alpha }\end{array}$ & N of Items \\
\hline $\mathbf{8 5 3}$ & $\mathbf{1 0}$ \\
\hline \multicolumn{2}{|c|}{ Sumber $:$ Hasil Perhitungan } \\
SPSS 20,O (data diolah), 2017
\end{tabular}

Dari data tabel diatas dapat dilihat bahwa hasil perhitungan uji reliabilitas menunjukkan cronbach's alpha pada variabel independent tambahan penghasilan adalah 0,853 , lebih besar dari 0,700 (batas reliabilitas), maka dinyatakan instrumen tersebut sangat kuat.

Tabel. Uji Reliabilitas Instrumen Variabel Tambahan Penghasilan (X)

\begin{tabular}{|l|l|l|l|}
\hline Pernyataan & $\begin{array}{l}\text { Cronbach's } \\
\text { Alpha if } \\
\text { Item } \\
\text { Deleted }\end{array}$ & $\mathbf{r}_{\text {alpha }}$ & Reliabel \\
\hline Item 1 &, 854 & 0,700 & Reliabel \\
\hline Item 2 &, 815 & 0,700 & Reliabel \\
\hline Item 3 &, 848 & 0,700 & Reliabel \\
\hline Item 4 &, 815 & 0,700 & Reliabel \\
\hline
\end{tabular}




\begin{tabular}{|l|l|l|l|}
\hline Item 5 &, 860 & 0,700 & Reliabel \\
\hline Item 6 &, 865 & 0,700 & Reliabel \\
\hline Item 7 &, 811 & 0,700 & Reliabel \\
\hline Item 8 &, 853 & 0,700 & Reliabel \\
\hline Item 9 &, 849 & 0,700 & Reliabel \\
\hline Item 10 &, 802 & 0,700 & Reliabel \\
\hline
\end{tabular}

Sumber : Hasil Perhitungan SPSS 20,0 (data diolah), 2017

Dari tabel diatas diperoleh nilai Cronbach's Alpha if Item Deleted ( $\mathrm{r}_{\text {alpha }}$ ) tertinggi pada item 6 sebesar 0,865 , dan nilai terendah pada item 10 sebesar 0,802 , sehingga dapat disimpulkan bahwa penelitian instrumen variabel tambahan penghasilan berupa kuesioner ini adalah reliable.

Tabel . Cronbach's Alpha Variabel Dependent Disiplin Kerja (Y) (Y) Reliability Statistics

\begin{tabular}{|r|r|}
\hline \multicolumn{1}{|c|}{ Cronbach's Alpha } & N of Items \\
\hline ,823 & $\mathbf{1 0}$ \\
\hline Sumber : Hasil Perhitungan \\
SPSS 20,0 (data diolah), 2017 \\
Dari data diatas dapat dilihat
\end{tabular}
bahwa hasil perhitungan uji reliabilitas menunjukkan cronbach's alpha pada variabel dependent disiplin kerja adalah 0,823 , lebih besar dari 0,700 (batas reliabilitas), maka dinyatakan instrument tersebut sangat kuat.

Tabel. Uji Reliabilitas Instrumen Variabel Disiplin Kerja

$$
\text { (Y) }
$$

\begin{tabular}{|l|l|l|l|}
\hline Pernyataan & $\begin{array}{l}\text { Cronbach's } \\
\text { Alpha if } \\
\text { Item } \\
\text { Deleted }\end{array}$ & $\mathbf{r}_{\text {alpha }}$ & Reliabel \\
\hline Item 1 &, 802 & 0,700 & Reliabel \\
\hline Item 2 &, 829 & 0,700 & Reliabel \\
\hline Item 3 &, 806 & 0,700 & Reliabel \\
\hline Item 4 &, 788 & 0,700 & Reliabel \\
\hline Item 5 &, 804 & 0,700 & Reliabel \\
\hline Item 6 &, 836 & 0,700 & Reliabel \\
\hline Item 7 &, 825 & 0,700 & Reliabel \\
\hline Item 8 &, 786 & 0,700 & Reliabel \\
\hline Item 9 &, 778 & 0,700 & Reliabel \\
\hline Item 10 &, 805 & 0,700 & Reliabel \\
\hline
\end{tabular}

Sumber : Hasil Perhitungan SPSS 20,0 (data diolah), 2017

Dari diatas diperoleh nilai Cronbach's Alpha if Item Deleted ( $\mathrm{r}_{\mathrm{a} \text { apha }}$ ) tertinggi pada item 2 sebesar 0,829, dan nilai terendah pada item 9 sebesar 0,778 , sehingga dapat disimpulkan bahwa penelitian instrumen variabel disiplin kerja berupa kuesioner ini adalah reliable.

\subsubsection{Analisis Regresi Linier Sederhana \\ Penelitian menggunakan regresi} linier sederhana untuk mengetahui pengaruh variabel bebas terhadap variabel terikat. Peneliti menggunakan bantuan program SPSS 20,0 for windows agar hasil yang diperoleh lebih terarah. Persamaan regresi linier sederhana yang digunakan adalah sebagai berikut :

$\mathbf{Y}=\mathbf{a}+\mathbf{b X}+\mathbf{e}$

Hasil perhitungan regresi linier sederhana yang diperoleh dengan menggunakan program SPSS 20,0 for windows dapat dilihat pada tabel berikut:

Tabel 4.33. Coefficients ${ }^{\mathrm{a}}$

\begin{tabular}{|c|c|c|c|c|c|}
\hline \multirow[t]{2}{*}{ Model } & \multicolumn{2}{|c|}{$\begin{array}{l}\text { Unstandar } \\
\text { dized } \\
\text { Coefficien } \\
\text { ts }\end{array}$} & $\begin{array}{l}\text { Stan } \\
\text { dard } \\
\text { ized } \\
\text { Coe } \\
\text { ffici }\end{array}$ & \multirow[t]{2}{*}{$\mathrm{T}$} & \multirow[t]{2}{*}{ Sig. } \\
\hline & B & $\begin{array}{l}\text { Std. } \\
\text { Erro } \\
\mathrm{r}\end{array}$ & Beta & & \\
\hline $\begin{array}{l}\text { (Cons } \\
\operatorname{tant} \text { ) }\end{array}$ & $\begin{array}{r}14,9 \\
45\end{array}$ & $\begin{array}{r}3,30 \\
5\end{array}$ & & & ,000 \\
\hline $\begin{array}{ll}1 \text { Tamb } \\
\text { ahan } \\
\text { Pengh } \\
\text { asilan }\end{array}$ &, 644 & ,080 & ,824 & $\begin{array}{r}8,09 \\
8\end{array}$ & ,000 \\
\hline
\end{tabular}

a. Dependent Variable : Disiplin Kerja

Sumber : Pengolahan data angket penelitian, 2017

Pada tabel 4.33. menunjukkan bahwa perhitungan diperoleh nilai konstanta (a) 14,945 dan b sebesar 1,001 , sehingga diperoleh persamaan regresi linier sederhana $\mathrm{Y}=14,945+$ $0,644 \mathrm{X}+\mathrm{e}$, dimana tambahan penghasilan mempunyai pengaruh yang signifikan terhadap variabel disiplin 
kerja. Hal ini dapat dilihat dari keterangan sebagai berikut :

Konstanta (a) sebesar 14,945 menunjukkan bahwa tanpa adanya variabel tambahan penghasilan terhadap disiplin kerja pada Organisasi adalah sebesar 14,945.

Tambahan penghasilan (X) sebesar 0,644 menunjukkan bahwa variabel tambahan penghasilan cukup berpengaruh positif dan signifikan terhadap disiplin kerja, artinya setiap terjadi peningkatan variabel tambahan penghasilan, maka akan berpengaruh positif terhadap peningkatan disiplin kerja.

\subsubsection{Uji t (Parsial)}

Uji t digunakan untuk mengetahui apakah secara parsial tambahan penghasilan (X) di Bappeda Kabupaten Serdang Bedagai berpengaruh secara signifikan atau tidak terhadap disiplin kerja. adalah :

Model hipotesis yang digunakan

1. Ho : $b_{1}=0$, artinya secara parsial tidak terdapat pengaruh yang positif dan signifikan dari variabel bebas tambahan penghasilan (X) terhadap disiplin kerja sebagai variabel terikat $(\mathrm{Y})$.

2. Ha : $b_{1} \neq 0$, artinya secara parsial terdapat pengaruh positif dan signifikan dari variabel bebas tambahan penghasilan $(\mathrm{X})$ terhadap disiplin kerja sebagai variabel terikat (Y).

Kriteria pengambilan keputusan:

1. Ho diterima jika $t_{\text {hitung }}<t_{\text {tabel }}$ pada $\alpha$ $=5 \%$

2. Ha diterima jika $t_{\text {hitung }}>t_{\text {tabel }}$ pada $\alpha$ $=5 \%$

$\mathrm{t}=8.098$

Analisis tabel diatas mengetahui pengaruh variabel independent secara parsial terhadap variabel dependent adalah variabel tambahan penghasilan (X) memiliki nilai $t_{\text {hitung }} 8.098>t_{\text {tabel }}$ 2,035 , artinya berpengaruh positif dan signifikan terhadap disiplin kerja $(\mathrm{Y})$.

\subsubsection{Koefisien Determinan $\left(\mathbf{R}^{2}\right)$}

Koefisien determinasi digunakan untuk mengukur seberapa jauh kemampuan model dalam menerangkan variansi variabel independent atau predictor-nya. Range nilai dari $\mathrm{R}^{2}$ adalah $0-1 . \quad 0 \leq \mathrm{R}^{2} \leq 1$ semakin mendekati nol berarti model tidak baik atau variansi model dalam menjelaskan amat terbatas, sebaliknya semakin mendekati satu model semakin baik. $\mathrm{D}=67.903 \%$ (dibulatkan 67,9\%)

Tabel . Hasil Uji R Square $\left(\mathbf{R}^{2}\right)$ Model Summary

\begin{tabular}{|l|l|l|l|l|}
\hline Model & $\mathrm{R}$ & $\begin{array}{l}\mathrm{R} \\
\text { Square }\end{array}$ & $\begin{array}{l}\text { Adjuste } \\
\mathrm{d} \mathrm{R} \\
\text { Square }\end{array}$ & $\begin{array}{l}\text { Std. } \\
\text { Error } \\
\text { of the } \\
\text { Estimat } \\
\mathrm{e}\end{array}$ \\
\hline 1 &, $824^{\mathrm{a}}$ &, 679 &, 669 & $\begin{array}{r}2,4426 \\
0\end{array}$ \\
\hline
\end{tabular}

a. Predictors : (Constant), Tambahan Penghasilan

Tabel diatas menunjukkan bahwa :

1. R menunjukkan korelasi sederhana, yaitu tambahan penghasilan terhadap disiplin kerja adalah sebesar 67,9\%. Artinya hubungannya erat, semakin besar R berarti hubungannya semakin erat.

2. $R$ square $\left(R^{2}\right)$ atau kuadrat $R$ menunjukkan koefisien determinasi adalah sebesar 0,679, artinya persentase sumbangan tambahan penghasilan terhadap disiplin kerja sebesar $67,9 \%$, sedangkan sisanya sebesar $32,1 \%$ dipengaruhi oleh variabel lain yang tidak diteliti oleh penelitian ini. Digunakan untuk satu variabel independent, sedangkan variabel independent lebih dari satu sebaiknya menggunakan Adjusted R Square.

3. Adjusted $R$ Square merupakan nilai $\mathrm{R}^{2}$ yang disesuaikan sehingga gambarnya lebih mendekati mutu penjajakan model dalam populasi. Dari tabel 4.34. dapat dibaca bahwa Adjusted $R$ Square $\left(\mathrm{R}^{2}\right)$ adalah $66,9 \%$, sedangkan sisanya $33,1 \%$ dijelaskan oleh faktor lain. 
4. Standart Error Of The Estimated adalah ukuran kesalahan prediksi. Standart Error Of The Estimated juga bisa disebut standart deviasi. Dalam kasus ini nilainya sebesar $2,44260 \%$. Semakin kecil standart deviasi berarti model semakin baik.

\section{KESIMPULAN}

Berdasarkan berbagai pengujian dan analisis data, dari penelitian ini dapat diperoleh beberapa kesimpulan mengenai Pengaruh Tambahan Penghasilan Terhadap Disiplin Kerja Pada Organisasi Universitas Muslim Nusantara Al Washliyah yaitu sebagai berikut :

1. Berdasarkan uji $\mathrm{t}$ diketahui bahwa hasil yang diperoleh dari tambahan penghasilan (X) memiliki nilai $\mathrm{t}_{\text {hitung }} 8.098>\mathrm{t}_{\text {tabel }} 2,035$, artinya berpengaruh positif dan signifikan terhadap disiplin kerja (Y). Maka Ha diterima karena $t_{\text {hitung }}>t_{\text {tabel }}$, sehingga tambahan penghasilan secara parsial cukup berpengaruh terhadap disiplin kerja pada Organisasi Universitas Muslim Nusantara Al Washliyah.

2. Berdasarkan uji regresi linier sederhana, maka diperoleh persamaan nilai konstanta sebesar (a) 14,945 dan b sebesar 1,001, sehingga diperoleh persamaan regresi linier sederhana $\mathrm{Y}=14,945$ $+0,644 \mathrm{X}+\mathrm{e}$, dimana tambahan penghasilan mempunyai pengaruh yang signifikan terhadap variabel disiplin kerja.

3. Nilai koefisien determinan $\left(\mathrm{R}^{2}\right)$ diperoleh sebesar 0,679 atau 67,9\% yang berarti bahwa variabel tambahan penghasilan cukup berpengaruh terhadap disiplin kerja pada Organisasi Universitas Muslim Nusantara Al Washliyah .

\section{DAFTAR PUSTAKA}

A. Sihotang. 2010. Manajemen Sumber Daya Manusia. Jakarta: Pradnya Paramita

Hasibuan, Malayu S.P. 2011. Manajemen Sumber Daya Manusia. Cetakan Kesembilan. Jakarta: PT. Bumi Aksara.

Lubis, Ade Fatma 2016. Metode Penelitian Akuntansi dan Format Penulisan Tesis. USU Press.

Mangkunegara, Anwar Prabu. 2012. Evaluasi Kinerja SDM. Bandung: PT. Refika Aditami.

Marihot, Tua Efendi Hariandja. 2013. Manajemen Sumber Daya Manusia, Pengadaan,

Pengembangan,

Pengkompensasian, Peningkatan Produktivitas Pegawai. Jakarta: Grafindo

Panggabean, S., Mutiara 2012. Manajemen Sumber Daya Manusia. Bogor: Ghalia Indonesia

Panjaitan, DJ., Firmansyah. 2012. Pelatihan Pengolahan Data Statistik Dengan Menggunakan Spss. Prosiding Seminar Nasional Hasil Pengabdian 1 (1). 38-45

Rivai, Veithzal. 2011. Manajemen Sumber Daya Manusia Untuk Perusahaan. Edisi 2. Jakarta: PT. Raja Grafindo Persada.

Setyosari, Punaji. 2012. Metode Penelitian Pendidikan dan Pengembangan. Jakarta: Kencana.

Singodimedjo, Markum. 2010. Manajemen Sumber Daya Manusia. Surabaya: SMMAS.

Siagian, Sondang P. 2011. Manajemen Sumber Daya Manusia. Jakarta: Bumi Aksara.

Sugiyono. 2010. Metode Penelitian Kuantitatif, Kualitatif dan $R \& D$. Bandung: Alfabeda.

Sutrisno, Edi. 2010. Manajemen Sumber Daya Manusia. Cetakan Ketiga. Jakarta: Kencana Prenada Media Group.

Tahir, Muh. 2011. Pengantar Metodologi Penelitian Pendidikan. Universitas Muhammadiyah Makassar. 